\title{
Research on Physical Education Reforms in Higher Vocational Colleges from the Perspective of Life Physical Education
}

\author{
Can Qiu, Jinsong Zhao, Gang Wang \\ Jiangsu Province Xuzhou Technician Institute, Xuzhou, 221000, China
}

Keywords: Physical education reforms, Higher vocational colleges, Life physical education

\begin{abstract}
With the continuous development of society, people's understanding of physical education is also deepening. In recent years, the idea of lifelong physical education has aroused the extensive attention of physical educators in higher vocational colleges. It has become an important direction of the reform of physical education in colleges. From the perspective of lifelong physical education, this paper examines the problems existing in the current physical education in higher vocational colleges and puts forward the corresponding solutions to provide some references for the relevant researchers.
\end{abstract}

\section{Introduction}

Lifelong physical education is that people have the awareness and behaviorsof physical education and physical exercise in their life time. Teachers should guide the students to establish lifelong sports consciousness, which will have an important positive impact on students after entering the social lives, work and social communication, at the same time to keep students' physical health can also play a decisive role. In the process of physical education in higher vocational colleges, it has been advocated that health is the first. Under the concept of physical education, teachers can achieve the comprehensive and healthy development of students. The physical education teaching in Higher Vocational Colleges to realize lifelong sports, they must realize the fusion between life and sports, the process to enable students to understand the connotation of sports life and practice training, gradually realize that sports is an important part of human life. Therefore, in the process of sports teaching in higher vocational education, must be based on the features of physical education. Paul, a German educator, put forward the idea of lifelong education, which has attracted the attention of all over the world. Paul emphasized the status and role of physical education in lifelong education, he advocated the lifelong education and physical education combined, sports and art, morality, intelligence and civic activities to achieve common development, this is the concept of lifelong sports. Lifelong physical education refers to the physical exercise and physical education as an indispensable part of life. It has the characteristics of universality and continuity, which affects and changes the school physical education to a great extent.

\section{Existing Problems of Physical Education inHigher Vocational Colleges from the Perspective of Lifelong Physical Education}

Backward Education Ideas.In the physical teaching in higher vocational colleges, both teachers and students of lifelong physical education is lack of understanding. The connotation of the lifelong sports is poorly understood. It is mainly due to the life-long physical education in higher vocational colleges have the necessary publicity and guidance. In the long-term teaching activities in higher 
vocational colleges, physical education students pay more attention to physical education, training the neglect of student sports interest, sports consciousness and exercise ability, some students in classes tend to hold a perfunctory and perfunctory attitude, no understanding of sports and the importance of lifelong physical education, students also lack of sense of lifelong sports. As some vocational education is not clear in the teaching planning and thinking, and understands the importance of physical education in higher vocational education is insufficient, this is not to mention the concept of lifelong sports. People's temperament, ability, conditions vary, different sports have different motion characteristics. As a result, it may not only help the physical and mental health of students, but also may be due to improper methods, such as excessive pressure on the physical and mental damage caused by students. At present, the phenomenon of emphasizing technology and light theory exists in the physical education teaching of Higher Vocational Colleges in our country. Under the guidance of the traditional teaching concept, the teaching of physical education in higher vocational colleges is only to improve the students' physical fitness. Improve the students' sports skills as the main teaching objectives, thus ignoring the cultivation of good habits of students, which is detrimental to the formation of students' lifelong sports consciousness.

Single Teaching Model.At present, competitive sports is still the main content of the higher vocational colleges sports teaching materials in China, and more and more comprehensive modern sports more strong, covering leisure and entertainment, fitness, adventure, fighting and other direction, the choice in sports has become increasingly diversified. The traditional gymnastics, track and field, basket volleyball and other projects due to the difficulty of the movement, the higher requirements of physical quality and the content of education and other reasons cannot meet the needs of modern physical education. At the same time, the traditional teaching methods and teaching content cannot stimulate students' interest in sports, but also cannot meet the actual needs of students. Therefore, students are generally not interested in physical education. The survey shows that half of the students are not interested in the content of physical education. Students cannot form a sense of awareness and action. The scientific and reasonable choice of teaching methods is an important way to improve the teaching effect due to the traditional examination oriented education. The basic sports students in higher vocational colleges in our country are relatively weak. Therefore, physical education teachers in higher vocational colleges must be able to seek scientific and efficient teaching methods to improve students' interest in learning and learning initiative in order to improve teaching effectiveness and improve students' physical fitness. At present, the development of physical education curriculum in higher vocational colleges is still dominated by some traditional teaching programs. The monotony of teaching content also affects the students' interest in learning. With the development of mass sports, physical education curriculum must follow the pace of the times.

Unprofessional Teaching Team.In the process of physical education, teachers, as the leading role of teaching, the level of their comprehensive level directly affects the students' learning. The professional level of teachers teaching level is not high, the serious role in implementing the idea of lifelong sports in higher vocational colleges, which is also an important factor to improve the teaching quality of higher vocational colleges. It lacks of lifelong physical education consciousness, as long as students in the physical implementation of the standard is complete the task of physical education. On the teaching evaluation, it is too much emphasis on the scores of the standard and the examination, ignoring the comprehensive evaluation, and the load of the students in the class and the practice. To sum up, the traditional physical education teaching mode has restricted the development of students' subjective consciousness, personality, creative thinking and practical ability. Obviously, this method cannot adapt to the new era of higher vocational college physical 
education teaching. Some higher vocational colleges in the teaching field and lack of equipment has led to these higher vocational colleges cannot realize the diversification of teaching content, but in the actual teaching process in strict accordance with the provisions of the textbook to PE teaching. This will give students a certain illusion that sports cannot absorb more knowledge. In this way, after graduation into the community, students will no longer have more interest in sports, so it cannot achieve lifelong sports.

\section{Reform Strategies of Physical Education in Higher Vocational Colleges from the Perspective of Lifelong Physical Education}

Upgrade Education Ideas. According to the idea of lifelong education and the development direction of Chinese education, the school sports will be transformed into the educational thought. Therefore, the sports teaching reform in normal colleges must change the idea first, lifelong sports as the guiding ideology, to establish a correct concept of lifelong physical education, to fully understand the function and role of physical education, to cultivate students' interest in sports, to enable students to develop the habit of sports to promote students' thinking and creativity and personality development. Higher vocational colleges should set up the consciousness of lifelong physical education to update knowledge, establish the structure of knowledge and ability. We must put the cultivation of lifelong sports awareness in an important position. They do not recognize the positive role of sports in the growth and life of people, and more to regard it as a burden on schoolwork. Therefore, the higher vocational colleges should devote themselves to the change of the students' misunderstanding of sports, to establish a positive attitude towards sports, as a kind of active behavior and habit. Higher vocational colleges should make full use of the campus radio station, the official website of the school, the campus forum and other channels, to increase the publicity of sports, in imperceptible in the students to be infected by sports. In addition, higher vocational colleges can hold a variety of sports competitions, through the game to expand the influence of sports on campus. Higher vocational colleges can hold lectures for students to understand the various sports knowledge, sports knowledge frontier, have interested in participating in sports, to enable students to participate in physical exercise independently, gradually make physical exercise has become a part of my life.

Enrich Teaching Models.With the continuous development of the reform of physical education in higher vocational colleges, higher vocational colleges should change the traditional way of practice teaching. We should gradually improve the physical education teachers' teaching design ability to master the use of a variety of teaching methods for teaching, and flexible use of teaching content in order to improve students' interest in learning, improve teaching effectiveness. Teachers should realize the diversified sports teaching organization form under the concept of lifelong sport ideological guidance, organization of sports teaching in higher vocational colleges must be able to accurately reflect the trend of the current teaching reform, to construct various teaching forms to meet the different needs of students, provide the broader development space for the development of students' comprehensive qualities the. In order to promote the application of the idea of lifelong physical education in higher vocational colleges, higher vocational colleges should pay attention to the reform of physical education teaching mode. In this regard, physical education teachers should stimulate student's interest in learning as a starting point. At present, the teaching materials of physical education in higher vocational colleges should be guided by the idea of lifelong physical education. The teaching content in higher vocational colleges, higher vocational colleges sports should be based on the physiological and psychological needs of students to compile, let the students in physical exercise can also give full play to their own value, to enrich the teaching 
contents, teaching model can offer some practical subjects, in order to achieve the comprehensive and diversified teaching contents. It is necessary to combine theory with practice in the course of making the teaching content, and combine the classroom teaching with the extracurricular exercise to establish the concept of lifelong physical education from the aspects of thought and action.

Cultivate Professional Teachers. The teacher is the leading factor of the physical education and the student is the main body of the teaching class. The teacher is the student studies the important instruction, the student must do well the physical education the premise is under teacher's scientific instruction. Lifelong physical education should attach importance to teachers' positive leading role. Therefore, teachers should constantly improve their professional level and teaching level, so as to improve the teaching effect. In the reform of physical education, the key is to improve the overall level of teachers' team, physical teachers in higher vocational colleges. It is the main force to promote the reform of physical education, sports science in higher vocational colleges. Therefore, must be based on the existing problems of teachers in higher vocational colleges to strengthen the continuing education of teachers, the education level of teachers and improve the knowledge, supplement and development, improving the teachers' professional basic theory and other related disciplines in order to maintain the level of knowledge, knowledge and technology, reasonable structure, adaptability and advance. In addition, the teachers should use higher vocational colleges favorable conditions, learning a foreign language and computer, understand and master the research methods of sports related subjects, actively writing papers. Therefore, the future success of physical education in higher vocational colleges, the talent training depends on the quality of teachers, strengthen the construction of teaching staff in higher vocational colleges, improve the professional level of teachers is the basic prerequisite for reform and development of higher vocational colleges sports. In the new era, only good physical education teachers in higher vocational colleges can train qualified personnel with high quality.

\section{Conclusion}

There are some problems in the traditional physical education of higher vocational colleges in our country, such as the backward teaching concept, single teaching method and the unprofessional teachers. The colleges should update teaching ideas, enrich the teaching methods, and cultivate excellent teachersto cultivate the habits of lifelong sports of students to benefit them all through their life.

\section{References}

[1] Zhang Huanchen, Research on Contemporary College Students Life-long PhysicalEducation [J].Journal of Hunan Industry Polytechnic, 2016, 16(1): 114-116.

[2] Xi Jie, Reform on Higher Vocational Education and Life-long Education [J].Journal of Ningbo University of Technology, 2011, 23(3): 89-91.

[3] Li Jianyuan, Research on the Reform and Development of HigherVocational Education Under the Concept of Life-long Education [J].Industrial Technology \& Vocational Education, 2015, 13(4): 65-67.

[4] Wang Lin, Zhou Yingfang, The Value Orientation and Reform Trend of Life-long Physical Education in Chinese Higher Education [J].Journal of Jilin Sport University, 2013, 29(6): 31-32. 